\title{
Epidemiological profile of workers with musculoskeletal disorders of a supermarket company
}

\author{
Perfil epidemiológico dos trabalhadores com distúrbios \\ musculoesqueléticos de uma rede de supermercados
}

\author{
Marcia Benites da Silva $^{[\mathrm{a}]}$, Caren Lara Martins Picasso ${ }^{[\mathrm{a}]}$, Miriam Pilla Rosito ${ }^{[\mathrm{b}] *}$ \\ [a] Universidade Feevale, Novo Hamburgo, RS, Brazil \\ [b] Pontifícia Universidade Católica do Rio Grande do Sul (PUCRS), RS, Brazil
}

\begin{abstract}
Introduction: The epidemiological profile is considered a sensitive indicator of living conditions and the disease process. The musculoskeletal disorders are the most common causes of pain and can lead to disability or restriction of daily activities. These disorders take the name of RCT/OWRD when they are associated with work activities and may be associated with risk conditions at work. Objectives: To describe the epidemiological profile of supermarket workers with musculoskeletal disorders under treatment at a physiotherapy clinic in the city of Porto Alegre, Brazil. Methods: This was a cross-sectional, observational study which used retrospective data collected from 360 records of patients treated from January 2010 to December 2011 in a physiotherapy clinic that provides health services for a supermarket chain. Results: There was a predominance of females (73.9\%), aged 30-39 years (35.1\%); 63.0\% reported being single and
\end{abstract}

* MBS: grad., e-mail: marcia.benites@gmail.com CLMP: MSc, e-mail: carenlara@feevale.br MPR: MSc, e-mail: mprosito@terra.com.br 
73.4\% lived in Porto Alegre. The most commonly reported occupation was cashier (31.2\%). The main reasons for referral to physiotherapy treatment were low back pain (21.4\%), neck pain (19.7\%), pain (16.1\%), subacromial bursitis (13.9\%) and back pain (12.2\%). Among the signs and symptoms $95.8 \%$ of the sample reported pain in chronic phase. Conclusion: The prevalence of musculoskeletal pain was high in this group. The presence of pain can disable the worker for daily activities and physiotherapy becomes the therapeutic procedure of choice for their rehabilitation.

Keywords: Occupational health. Occupational injuries. Physiotherapy. Musculoskeletal pain.

\section{Resumo}

Introdução: O perfil epidemiológico é considerado um indicador sensível das condições de vida e do processo saúde-doença. Os distúrbios musculoesqueléticos são as causas mais frequentes de dor e podem levar à incapacidade ou limitação das atividades diárias. Esses distúrbios, quando associados ao trabalho, levam o nome de LER/DORT e podem estar associados às condições de riscos no trabalho. Objetivos: Traçar o perfil epidemiológico dos trabalhadores com distúrbios musculoesqueléticos de uma rede de supermercados, atendidos em uma clínica de fisioterapia de Porto Alegre (RS). Materiais e métodos: Estudo de corte transversal, observacional, com coleta retrospectiva de dados de 360 prontuários de pacientes atendidos no período de janeiro de 2010 a dezembro de 2011 em uma clínica de fisioterapia que presta serviços de saúde para uma rede de supermercados. Resultados: Houve predomínio do gênero feminino (73,9\%), na faixa etária dos 30-39 anos (35,1\%); 63,0\% declararam-se solteiros e 73,4\% residentes em Porto Alegre. Em relação à ocupação, a maior frequência foi para o setor frente de caixa (31,2\%). Os principais motivos de encaminhamento para a fisioterapia foram lombalgia (21,4\%), cervicalgia (19,7\%), dor (16,1\%), bursite subacromial (13,9\%) e dorsalgia (12,2\%). Dentre os sinais e sintomas, 95,8\% da amostra mencionou a dor em fase crônica. Conclusão: A prevalência de dor musculoesquelética foi alta neste grupo. A presença de dor pode incapacitar o indivíduo para atividades diárias e laborais. A fisioterapia tornou-se o procedimento terapêutico eleito para sua reabilitação.

Palavras-chave: Saúde do trabalhador. Lesões ocupacionais. Fisioterapia. Dor musculoesquelética.

\section{Introduction}

Epidemiological research is based in the study of the distribution and determinants of events or health patterns in populations, and the use of research to control health issues (1). Epidemiological profile can be considered as a relatively sensitive indicator of living conditions, health and disease processes and population patterns. According to Brazilian Law No. $8,080 / 90$, health presents determining and conditioning factors such as eating habits, living conditions, water and sanitation, the environment, work, income, education, transportation, and leisure, among others, and these are also factors that are responsible for shaping the profile of a community, which must occur with a clear compromise with the transformation of the health conditions of the population, favoring the development of a health system that understands the health and disease process as part of social organization (2).
Population increase, the incorporation of new technologies and work intensification have brought consequences such as an expressive I injury increase among the working class. These injuries, classified as RSI/WMSDs (Repetitive Strain Injury and Workrelated Musculoskeletal Disorders), refer to musculoskeletal changes associated with occupational activities and risk conditions at work (3).

Musculoskeletal disorders (MSDs) are characterized by inflammation and/or degeneration of muscles, bones, joints, tendons, ligaments, bursa, fascia, connective tissue, cartilage and aponeurosis. They are the most frequent cause of pain and may result in disability or limitation for daily activities $(4,5,6)$.

RSI/WMSDs are common health conditions and represent one of the main causes for disability in active populations, generating costs for public health (7). MSDs may result in consequences not only for workers, but also for institutions. The main 
consequence is a decrease in productivity which results from the reduction of the work force due to employee's medical leave and work repositioning or work adaptations for employees that return to work after a medical leave. This results in substantial impact on healthcare quality and costs (8).

RSI/WMSDs present a multi-causal dimension and biomechanical, physiological and psychological factors are among the main causing factors. Biomechanical factors involve inadequate adverse posture; mechanic compression and repetitiveness. Physiological factors include hormone changes; the bone and joint structure of each individual worker; obesity; general health status, height, among others. Psychological factors refer to stress, individual psychological profile as well as social relations. All of these factors make occupational disease a complex and degrading condition for an individual, directly influencing the balance between body and mind and the individual's socioeconomic and cultural scenario (9).

In 2010, according to data from the Ministry of Social Security (10), 701496 cases of work related accidents were reported in Brazil. These incidents were qualified as typical (due to characteristics related to the professional activity carried out by the employee), commute (accidents with took place while worker was commuting to and from work) and occupational disease (caused by any type of occupational disease related to professional activities listed by Social Security services). In the same year, the state of Rio Grande do Sul registered 58,237 cases, of which 10,697 occurred in the city of Porto Alegre.

Health aggravations due to work related accidents may or may not cause temporary or permanent disability. Thus, the rehabilitation of workers becomes one of the greatest contemporary challenges for public health in Brazil (11).

According to the Brazilian Physiotherapy and Occupational Therapy Federal Council on Resolution No. 259, dated December 18, 2003 :

Attributions of the physiotherapist who provides health care for workers, regardless of working place, include: [...] identifying, evaluating and observing environmental factors which may constitute risks to a worker's functional health, in any stage of the production process, alerting the employer as to the existence of these risks and possible results; carrying out the biomechanical analysis of worker's productive activity, considering different task demands on static and dynamic efforts [...] (12).

Epidemiological evidence by the Ministry of Social Security on medical leave due to accidents is expressive - be these typical, commute or occupational disease accidents - , as well as regulating interventions proposed by the Ministry of Health, with the Occupational Health National Policy, which seeks to reduce accidents and occupational diseases by stimulating health promotion, rehabilitation and surveillance measures.

Assessment of professional, working conditions and occupational stress profiles may subsidize programs to adequate the work process (13). Keeping this perspective in mind, the objective of this study was to identify the epidemiological profile of supermarket workers treated for musculoskeletal disorders at a physiotherapy clinic in the city of Porto Alegre, Brazil.

\section{Materials and method}

A cross-sectional observational study was carried out using retrospective data collection from patient records.

The study analyzed the records of 360 patients treated from January 2010 to December 2011 in a physical therapy clinic located in the city of Porto Alegre, Brazil. This clinic is part of a multidisciplinary team of a company that provided healthcare services for a supermarket chain.

In order to be included in the study, the record being analyzed had to be from a patient with a proven employment relationship with the supermarket chain and a musculoskeletal disease as the reason for referral and/or by physiotherapy evaluation. Records that were excluded from the study belonged to patients that presented with a musculoskeletal disorder that was not related to their work activity.

In order to identify the workers' sociodemographic profile, the following data was collected from the records: age, sex, marital status, city of residence, occupation and work location (branch store within the supermarket chain).

To make up workers' health profile, the following information was collected: type of payment for physiotherapy services (private or supplementary health insurance), reason for physician referral (according 
to information found on patient records) and specialty of physician that referred patient to physiotherapy.

Signs and symptoms were investigated from data provided by the History of the Present Illness (HPI) and Physical Examination sections on the patient records. Reported musculoskeletal disorders were then classified as acute, sub-acute or chronic according to time of onset of signs and symptoms described in HPI, and classified according to Robbins et al. (14).

Complementary exams, information whether or not the worker was engaged in work activity at the time, if he/she was in medical leave or had been referred to The National Institute for Social Security (NISS) at the date of kinesiotherapy evaluation, as well as the number of sessions per patient were described according to data found on the records.

Physiotherapy treatment was group according to treatment technique: cryotherapy - the therapeutic use of cold; electrothermal and phototherapeutic - the use of electricity, hear and light to treat disease, and kinesiotherapy - the use of exercises for rehabilitation.

Data was collected, typed into a table using the Microsoft Excel ${ }^{\mathrm{TM}}$ software and then submitted to statistical analysis through software SPSS 17.0. Significance level $(\alpha)$ of $5 \%$ was used as a decision criteria.

This study was submitted to the Ethics Committee at Feevale University and approved on September 11, 2012 under Report No. 94,829, Plataforma Brasil/ CAAE 04690712.6.0000.5348.

\section{Results}

Results refer to a sample of 360 participants. There was a significant $(\mathrm{p}<0.001)$ predominance of females $(73.9 \%)$ in relation to males $(26.1 \%)$. Average age was $34.6 \pm 10.5$ years, with a minimum age of 17 years and a maximum age of 76 years. There was a significantly high $(\mathrm{p}<0.001)$ proportion of participants between the ages of 30 and 39 years $(35.1 \%)$ and between the ages of 20 and 29 years $(32.3 \%)$ when age was analyzed by age groups.

For marital status, the group that declared to being single was more significant $(\mathrm{p}<0.001)$, with $63.0 \%$ of participants. Among others, $31.5 \%$ declared to being married, $2.2 \%$ divorced, $1.7 \%$ separated and $1.7 \%$ widowed.
Regarding city of residence, $73.4 \%$ reported living in Porto Alegre, while the other $26.6 \%$ remaining participants reported living in the Porto Alegre Metropolitan Area, with special mention to the cities of Alvorada (8.5\%), Viamão (9.1\%) and Canoas (3.7\%).

When occupation was analyzed, greater frequencies were noted in occupations such as cashier (31.2\%), as well as occupations performed in the bakery and warehouse, representing $10.6 \%$ of total sample (Graph 1). Work performed at cash registers involves duties such as a cashier, cashier assistant and supervisor, security and support. In this study, working at the bakery involves occupations such as baker and confectioner and working at the warehouse involves occupations that deal with sorting and carrying merchandise, stocking, replacing and checking products.

As to work location, $28.7 \%$ of workers were stationed in stores in Northern Porto Alegre, $27.0 \%$ in the stores in Southern Porto Alegre, 12.8\% in the Eastern part of the city and $11.1 \%$ in the Porto Alegre Metropolitan Area.

Type of funding for physiotherapy treatment was exclusively provided by supplementary health insurance $(100.0 \%)$. Most physician referrals were due to low back pain $(21.4 \%)$, neck pain $(19.7 \%)$, pain (16.1\%), subacromial bursitis (13.9\%) and back pain (12.2\%) (Graph 2).

In addition, $90.6 \%$ of referring physicians worked as orthopedic/traumatology physicians.

Regarding signs and symptoms, pain was referred by $95.8 \%$ of the sample. Also, $30.0 \%$ of participants reported muscle contracture, $19.4 \%$ limited range of motion (ROM), $16.9 \%$ edema and $15.6 \%$ loss of muscle strength (Graph 3).

As to stage of injury, $83.6 \%$ of participants presented with chronic injuries, $12.5 \%$ with sub-acute injuries and $4 \%$ with acute injuries. Time of onset of signs and symptoms was more prevalent for periods of up to 1 month (43.5\%) and for periods of 1 to 6 months (34.5\%) (Graph 4).

Complementary exams showed that $55.3 \%$ of participants had been submitted to X-Ray, $54.0 \%$ to ultrasound and $9.7 \%$ to nuclear magnetic resonance and electromyoneurography.

The most prevalent physiotherapy techniques used to treat patients were kinesiotherapy (99.7\%), electrothermal and phototherapy (98.6\%) and cryotherapy (23.7\%) (Graph 5). 


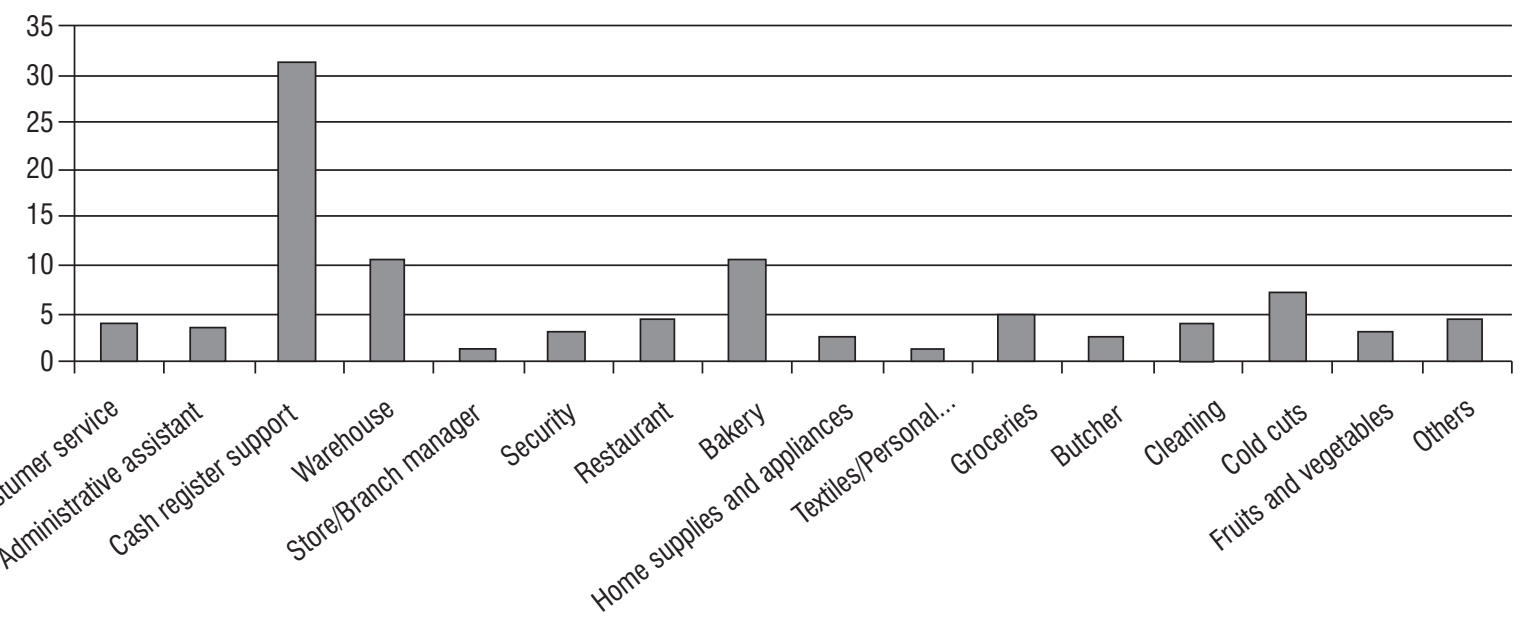

Graph 1 - Occupations (\%)

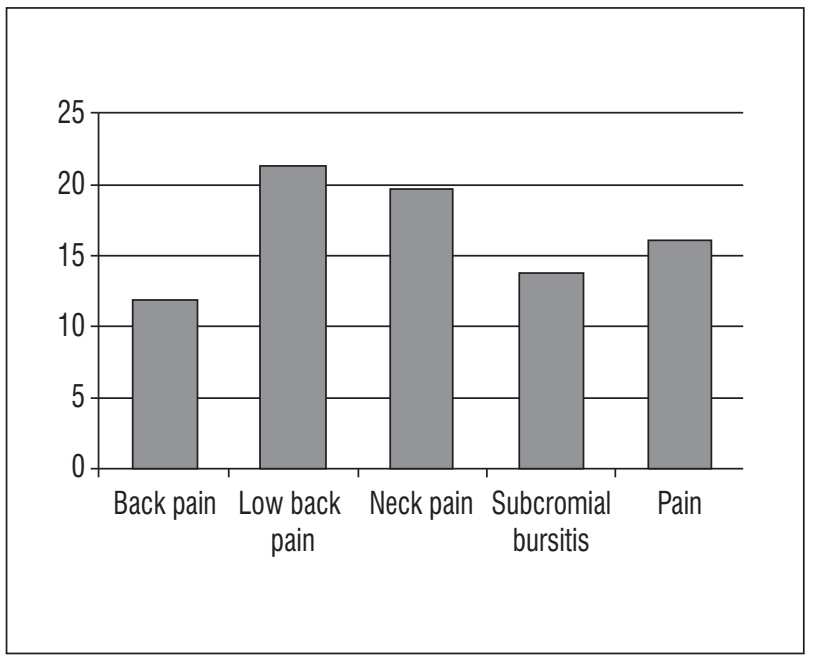

Graph 2 - Reason for physician referral

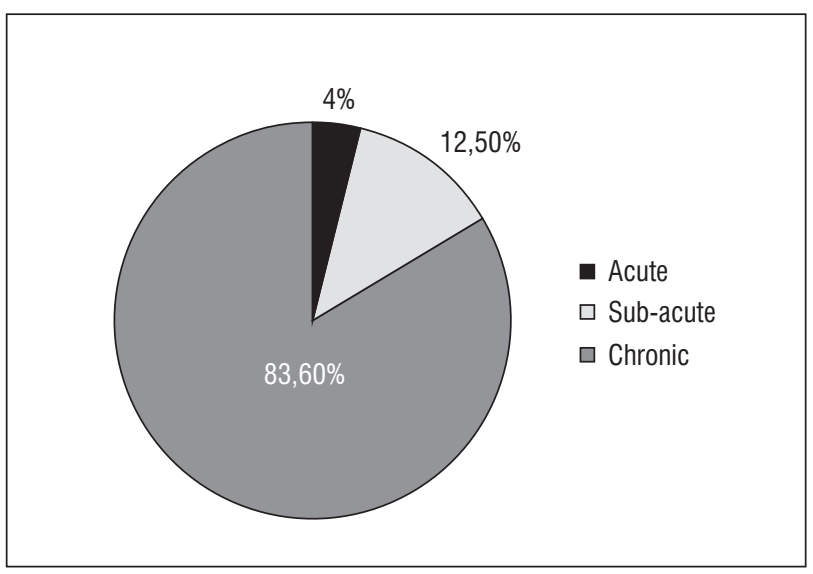

Graph 4 - State of injury

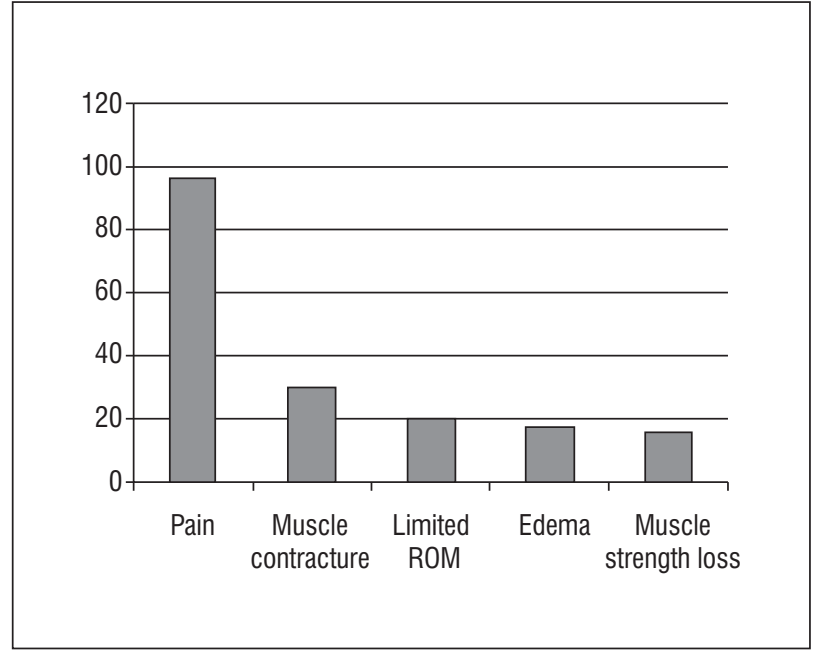

Graph 3 - Signs and symptoms

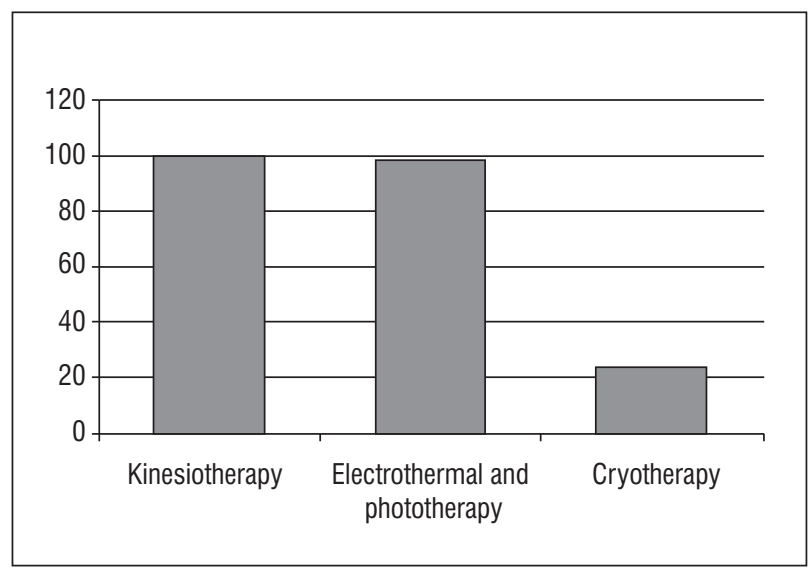

Graph 5 - Physiotherapy treatment 
The average number of physiotherapy sessions was nine. Looking at groups of sessions, the most prevalent was from one to five sessions (32.5\%) and from six to ten sessions (34.7\%). In addition, $4.2 \%$ of participants were treated for over 40 physiotherapy sessions.

Regarding employment relationship, $57.0 \%$ of participants were actively working, $27.9 \%$ had been referred to The National Institute for Social Security (NISS), $12.8 \%$ were on medical leave and $2.3 \%$ were on vacation at the time of kinesiotherapy evaluation.

The presence or absence of pain was compared to gender and a statistically significant association ( $p$ $<0.01$ ) was found, showing the association between the female sex and pain. No significant association $(p>0.05)$ was found when pain was compared to age groups, showing that pain does not depend on age for this sample. In addition, the most commonly afflicted age group was 30 to 39 years, followed by 20 to 29 years for both the group that referred pain and the group without pain.

When pain was compared to work location, no significant statistic association was found ( $p>0.05)$ When occupation was compared to pain a significant statistic association was found $(\mathrm{p}<0.05)$, showing that cash register support workers are associated to pain in a significant way, while the association occurred without the presence of pain for warehouse and grocery employees. There was no significant association for other occupations due to small sample size.

\section{Discussion}

The present study found a higher concentration of single women between the ages of 30 to 39 years and 20 to 29 years who reside in the city of Porto Alegre, in Southern Brazil, and who worked mainly as cash register support in stores located in the Northern and Southern regions of this city. These women were associated with the presence of pain.

According to the Monthly Employment Research (MER) carried out in 2011 in six Brazilian metropolitan areas (Recife, Salvador, Belo Horizonte, Rio de Janeiro, São Paulo and Porto Alegre), the female population represents the most active working-age population (WAP), with $53.8 \%$ of employed women, and over the past 8 years this behavior has remained the same for all six metropolitan areas as well as for each area individually. In Porto Alegre and the Porto
Alegre Metropolitan Area, the 2011 WAP was composed by $53.3 \%$ of females and $46.7 \%$ males (15). Women represented up $45.4 \%$ of the occupied population. This percentage is even higher when compared to the WAP, however, according to the Brazilian Institute for Geography and Statistics, participation of women in the occupied population has a tendency to increase (2.4 percentage points in relation to 2003.)

In 2011, data from the MER showed that the distribution of the working-age population in the Porto Alegre metropolitan area according to age group, reported $2.8 \%$ of individual between 25 and 49 years and $12.2 \%$ of individuals between 18 and 24 years in 2011. The occupied population was $61.9 \%$ and $14.9 \%$ respectively, data which corroborates with the age group that makes up the socio-demographic profile found for the sample in this study (15).

According to Santos (16), RSI/WMSDs are not an exclusively female condition, but affects mainly women who work in positions where repetitive moments are dominant, with higher demand of attention, manual skills, dexterity and control over productivity. Ferreira et al. (17) tried to determine the prevalence of chronic low back pain in a population base adult sample residing in the city of Pelotas, Southern Brazil, and verify association with demographic, socioeconomic, behavioral ergometric and nutritional variables. The author found that among the 3,182 individuals in the study, prevalence of chronic pain was higher among females (56.81\%). This is similar to data found in a study conducted in the Netherlands, which showed the predominance of chronic pain in women (53.9\%), and to a study involving the population of the city of Salvador, where $55.4 \%$ of individuals presenting with chronic pain were females (18).

Women have a greater risk than man for chronic low back pain. Some studies attribute this finding to an information bias. However, this finding is plausible, since women combine home tasks with the work outside of the home, where they are exposed to ergonomic loads, especially repetitiveness, problematic working positions and work carried out at high speed. Besides, females present certain anatomical/ functional characteristics which may contribute to chronic low back pain (shorter stature, less muscle mass, less bone mass, more fragile joints that are less adapted to heavy physical strength, higher fat weight) (17).

The profile of the population in this study showed that employees use the complementary healthcare 
insurance that is offered by employer in order to fund physiotherapy treatment. Most patients were referred to physiotherapy treatment by an orthopedic/traumalogy physician, which suggests a more specialized clinical diagnosis, since this is the medical area that studies disease and deformity of the locomotor system, as well as trauma related to the musculoskeletal system.

When characteristics of workers presenting with musculoskeletal disorders were collected, the study found a greater occurrence of neck and upper limb pain, which is a finding confirmed by previous studies.

Santos (16) verified the prevalence of pain in 61 cashiers and 12 stockers employed at stores from a supermarket chain in the city of Caxias do Sul, Southern Brazil, with a total of 73 workers ( $68 \mathrm{fe}$ males and 5 males) and found that $29 \%$ of cashiers reported upper limb pain, $15 \%$ low back pain and $11 \%$ neck pain. Among stockers, $26 \%$ reported low back pain, $23 \%$ upper limb pain and $14 \%$ neck pain. Galvão (19) tried to identify factors related to health and life quality in the work environment of 26 supermarket cashiers in the city of Paraíso do Tocantins, state of Tocantins. All participants were women and $35 \%$ reported work related pain, with over half of participants reporting back pain. Batiz et al. (20) studied eight supermarkets in two different cities in Brazil to identify risk factors to which supermarket cashiers were exposed. The population of this study was composed of 82 workers between 18 to 41 years and $83.75 \%$ were females. When complaints for this population were studied, the author found that $81 \%$ of participants reported low back pain, $54 \%$ shoulder pain, $50 \%$ back pain and $49 \%$ neck pain.

Chronic pain was among most frequent signs and symptoms. Some participants reported more than one pain complaint, for example: irradiating pain, pain located in a specific body part, pain during movement, pain while performing activities of daily living, etc.

Garcia and Torres Neto (18) determined the clinical profile of employed patients and those under medical leave who were being treated at a chronic pain outpatient care unit at the Federal University of the state of Maranhão university hospital from 2006 to 2010 . About $40 \%$ of patients were employed and $21.3 \%$ were under medical leave. The main diagnosis was low back pain (32.6\%), followed by osteoarthrosis $(7.7 \%)$, among others. When data from employed patients was analyzed separately, the median for pain onset was $36 \pm 12.6$ months.
Participants in this study presented with higher back pain complaints and when authors tried to correlate these findings with the most commonly performed complementary exams, they found that most referrals to physiotherapy treatment had been made by orthopedic physicians, which can be related to fewer MRIs, due to greater specificity during clinical care, as well as the high cost and need for previous authorization by the healthcare insurance company to have exam performed. According to Matos and Gusmão (21), MRIs are in fact not necessary for all patients with radiculopathy. This exam is reserved for cases where image will guide treatment, which is useful for patients with neurological signs and symptoms such as lameness and a suspected central or foraminal stenosis. Although it is indicated in restricted situations, requests for this exam happen in over $75 \%$ of low back pain cases. Bearing in mind that the first professional to have contact with these patients is usually not a specialist, the increase on MRI prescription may lead to overestimating its real value. This causes a high and unnecessary cost increase for the healthcare system and also induces diagnostic and therapeutic mistakes in case of falsepositives and or false-negatives.

$\mathrm{X}$-rays and ultrasounds are the most prevalent complementary exams found in this study. X-ray is the initial choice exam since it presents less operational costs, it is highly available and allows for evaluating fractures, luxations, degenerative processes, posture changes, tumors, etc. Ultrasound is a fundamental diagnostic method in evaluating musculoskeletal conditions in urgent care, assuring diagnostic and therapeutic resolution. Ultrasound enables detecting and characterizing soft tissue injuries, especially muscle, tendon and ligament injuries, and may also be used for searching foreign bodies, as well as screening (22).

Another characteristic of the sample is the higher frequency of employed workers normally carrying out their work activities, even with the high prevalence of pain. Musculoskeletal disorders may cause great impact and findings such as reported pain (95.8\%), muscle contracture (19.4\%), range of movement limitation (16.9\%), edema (15.6\%) and decrease in muscle strength $(15.6 \%)$ confirm this affirmation. Physiotherapy is widely prescribed for the treatment of these conditions as its main objective is to restore physical function. Patients underwent an average of nine physiotherapy sessions and most commonly 
used therapeutic resources were the association of kinesiotherapy techniques with electrothermal and phototherapy and cryotherapy.

Patients with RSI/WMSDs are frequently referred to physiotherapy services. Many times, this is the first and sole therapeutic procedure and may be long term (23). Physiotherapists are qualified and legally apt to contribute towards prevention, promotion and restoration of workers' health with relevant preventive and therapeutic measures to reduce occupational diseases (12).

Data collection based on patient records review present strong limitations such as: lack of filling out and registering important information or missing information (24), for example, missing therapeutic outcome: patient was released from treatment or abandoned it; missing information on length of service. These were considered limitation factors for this study.

\section{Conclusion}

Prevalence of musculoskeletal pain among employees of a supermarket chain treated at a physiotherapy clinic in the city of Porto Alegre/Southern Brazil from January 2010 to December 2011 was high (95.8\%) and more prevalent in women $(73.9 \%)$ between 30 to 39 years (35.1\%) and 20 to 29 years (32.3\%) residing mainly in the city of Porto Alegre/ Southern Brazil, who were employed providing cash register support services, users of the complementary healthcare insurance provided by the employer and referred to physiotherapy treatment by an orthopedic physician. These women reported pain, limitation of range of movement, muscle contracture and edema. An association of kinesiotherapy, electrothermal and phototherapy and cryotherapy was used to provide physiotherapy treatment.

Authors believe that knowledge of the characteristics of this sample allows for responsible employers and professionals to plan for preventive and healing measures.

\section{References}

1. Soares DA, Andrade SM, Campos JJB. Epidemiologia e indicadores de saúde. In: Andrade SM, Soares DA, Cordoni Junior L, organizadores. Bases da saúde coletiva. Londrina: Eduel, 2001.

2. Araújo LM, Chaves ED, Moisés MS, Simpson CA. Perfil epidemiológico do bairro de Passagem de Areia do município de Parnamirim/RN: relato de experiência. In: Anais do 61. Congresso Brasileiro de Enfermagem; 7-10 dez 2009, Fortaleza, CE, Brasil. Fortaleza: Abeneventos; 2009 [cited 2012 Aug 19]. Available from: http://www.abeneventos.com.br/anais_61cben/ files/02067.pdf

3. Silva GM. Avaliação da sintomatologia osteomuscular através de um programa de escola postural em pacientes portadores de lesões por esforços repetitivos/ distúrbios osteomusculares relacionados ao trabalho, usuários de uma unidade de saúde no Município de Sapiranga - RS [monografia]. Novo Hamburgo: Universidade Feevale; 2008.

4. Fonseca NR. Distúrbios musculoesqueléticos em trabalhadoras de enfermagem [dissertação]. Salvador: Universidade Federal da Bahia; 2009.

5. Helliwell PS, Taylor WJ. Repetitive strain injury. Postgrad Med J. 2004;80(946):438-3.

6. Gurgueira GP, Alexandre NMC, Correa Filho HR. Prevalência de sintomas músculo-esqueléticos em trabalhadores de enfermagem. Rev Latino-Am Enfermagem. 2003;11(5):608-13.

7. Bültmann U, Franche RL, Johnson SH, Côté P, Lee H, Severin C, Vidmar M, Carnide N. Health status, work limitations, and return-to-work trajectories in injured workers with musculoskeletal disorders. Qual Life Res. 2007;16(7):1167-78.

8. Diniz KT, Miranda RM, Diniz ET, Moreira CH, Miranda RSS, Cabral Filho, JE. Capacidade laboral dos segurados do INSS portadores de LER/DORT que retornaram ao trabalho. ConScientiae Saúde. 2010;9(4):676-83.

9. Baú LMS. Fisioterapia do trabalho: ergonomia, reabilitação, legislação. Curitiba: Clãdosilva; 2002. 
10. Ministério da Previdência Social (Brasil). Anuário estatístico de acidentes do trabalho. 2010 [cited 2012 Mar 21]. Available from: http://www.previdencia.gov. br/dados-abertos/aeat-2010/

11. Brasil. Instituto Nacional do Seguro Social. Diretoria Colegiada. Instrução normativa INSS/DC n. 98, de 5 de dezembro de 2003. Aprova norma técnica sobre lesões por esforços repetitivos-LER ou distúrbios osteomusculares relacionados ao trabalho-DORT. Diário Oficial da União. 2003 dez 10 [cited 2012 Jan 30]. Available from: http://www81.dataprev.gov.br/ sislex/paginas/38/inss-dc/2003/98.htm

12. Brasil. Conselho Federal de Fisioterapia e Terapia ocupacional. Resolução no. 259, de 18 de dezembro de 2003. Dispõe sobre a Fisioterapia do Trabalho e dá outras providências. Diário Oficial da União. 2004 fev. 16 [acesso em 2012 jan 30]. Available from: http:// www010.dataprev.gov.br/sislex/imagens/paginas/38/inss-dc/2003/anexos/IN-DC-98-ANEXO.htm

13. Tomasi E, Facchini LA, Piccini RX, Thumé E, Silveira DS, Siqueira FV, et al. Perfil sócio-demográfico e epidemiológico dos trabalhadores da atenção básica à saúde nas regiões Sul e Nordeste do Brasil. Cad Saúde Pública. 2008;24(1):193-201.

14. Robbins SL, Cotran R, Kumar V, Collins T. Fundamentos de Robbins: patologia estrutural e funcional. 6. ed. Rio de Janeiro: Guanabara Koogan; 2001.

15. Ministério do Planejamento, Orçamento e Gestão (Brasil); Instituto Brasileiro de Geografia e Estatística. Pesquisa mensal de emprego: principais destaques da evolução do mercado de trabalho nas regiões metropolitanas abrangidas pela pesquisa. Rio de Janeiro: IBGE; 2012.

16. Santos DB. Prevalência de algias relacionas à coluna vertebral em trabalhadores de uma rede de supermercados de Caxias do Sul - RS [monografia]. Novo Hamburgo: Universidade Feevale; 2009.

17. Ferreira GD, Silva MC, Rombaldi AJ, Wrege ED, Siqueira FV, Hallal PC. Prevalence and associated factors of back pain in adults from southern Brazil: a population-based study. Rev Bras Fisioter. 2011;15(1):31-6.
18. Garcia JBS, Torres Neto E. Atividade laboral em pacientes atendidos em um serviço ambulatorial de dor crônica. Rev Dor. 2011;12(3):215-20.

19. Galvão JT. Saúde e qualidade de vida do operador de caixa de supermercado [monografia]. Palmas: Universidade de Brasília; 2012.

20. Batiz EC, Santos AF, Licea OEA. A postura no trabalho dos operadores de checkout de supermercados: uma necessidade constante de análises. Produção. 2009;19(1):190-201.

21. Matos MA, Gusmão MS. Valor diagnóstico da ressonância magnética na avaliação da dor lombar. Rev Salud Pública. 2008;10(1):105-12.

22. Lourenço RB, Lima GAF, Yonezak RT, Tanaka RT, Silva MRC, Francisco Neto MJ, et al. Ultrassonografia na avaliação das afecções agudas do sistema músculoesquelético: parte II: afecções traumáticas e procedimentos guiados por ultrassom. Rev Imagem. 2008;30(3):95-101.

23. Mendes LF. A contribuição da fisioterapia em grupo na recuperação e reabilitação de pacientes com LER/ DORT [tese]. São Paulo: Universidade de São Paulo; 2008.

24. Weber CAT. O prontuário médico e a responsabilidade civil. Porto Alegre: EDIPUCRS; 2010.

Received: 05/29/2014

Recebido: 29/05/2014

Approved: 04/07/2015

Aprovado: 07/04/2015 
